\title{
Customer Relationship Management (CRM) Training In Increasing Business Sales During The Covid-19 Pandemic
}

\author{
Adi Lukman Hakim ${ }^{1 *}$, Mega Barokatul Fajri², Erna Nur Faizah ${ }^{3}$ \\ ${ }^{1,2,3}$ Faculty of Economics and Business, Universitas Muhammadiyah Lamongan, Lamongan, \\ 62218, Indonesia \\ ${ }^{*}$ Corresponding Author: \\ Email: adilukmanhakim123@gmail.com
}

\begin{abstract}
.
The Covid-19 pandemic demands that businesses go digital. Not only products must be marketed through technology, but the way of communication with consumers must also be arranged systematically to stabilize income. Among a number of tools designed to answer customer retention demands, CRM software was chosen because this tool can accommodate consumer data, business data, track consumer interactions, and track company prospects. The purpose of this activity is to conduct training and assistance in implementing Customer Relationship Management in increasing sales during the pandemic. This method uses a descriptive qualitative approach with training design in using Customer Relationship Management software. Instruments in the form of learning experience and literature study. This community partnership program involves business start-ups within the Muhammadiyah University of Lamongan, especially students majoring in Accounting and Management. The results of this study indicate that the application of CRM has an effect as an effort to increase business sales during the pandemic with a series of strategic CRM processes, operational CRM, analytical CRM. Essentially, both upper, middle, and even lower customers need good and quality service, it's just that the levels are different. When start-up actors apply the right and good CRM, it will automatically increase customer satisfaction which has an impact on increasing business sales.
\end{abstract}

Keywords: customer relationship management, start-up, company portfolio; business sales

\section{INTRODUCTION}

The Covid-19 pandemic has changed the lifestyle of many people. The impact of this health disaster also touched many business sectors, including the culinary, retail, travel, tourism and other sectors. Chef Gun Gun said that the decline in restaurants around the world touched $70 \%$, in some places it was even worse, down to $80 \%$ due to the spread of the Corona virus (Perkasa, 2020). Not only that, Sutrisno Iwantono (Chairman of Public Policy Apindo/Vice Chairperson of PHRI) reported that for the January 2020 period, Indonesian exports decreased by $7.16 \%$ compared to December 2019, and decreased by $3.71 \%$ compared to the January 2019 period. (Laucereno, 2020). This incident certainly requires business people to rack their brains in order to retain the consumers they have got. During this pandemic, business owners are no longer able to reach consumers directly, even consumer service is carried out with 
various efforts that minimize physical contact. With this changing situation, the implementation of product marketing has changed from traditional to modern ways through the use of technology.Even though the government has voiced that there will be a new normal, this also cannot restore the conditions of interaction between business people and consumers as before. Businesses around the world will soon be operating again as a form of resurgence from the pandemic, and consumers are required to follow health protocols if they want to shop in person, such as requiring the use of masks, limiting visitor capacity, and checking their body temperatures to maintain the health and safety of each consumer. However, this also does not fully create a sense of comfort for consumers. Therefore, business people are asked to provide services to buy items online or pick up items by the roadside / contactless.

This situation is certainly a challenge that may be new for some new business players. Besides having to compete to show the superiority of the products and services they have; they are also asked to find ways to attract customers and retain existing customers. It's no secret that acquiring new customers is more difficult financially and time-consuming than maintaining customer retention. Consumer retention can be interpreted as consumer behavior to continue to use the services/products of business people and spend their money next time. (Singh, R \& Khan, 2012). Therefore, knowing how to get consumers and keep them for long-term investment needs to be known by business people at the start-up level.Go digital does not only apply to its products/services, but also access to communication with customers in order to support their business. Establishing good relationships with consumers is not an easy business, but this step is believed to be able to grow a business to become more successful. Customer Relationship Management (CRM) software is used to store consumer data, business data, and track customer interactions, as well as track processes. The use of hardware or software through applications has been widely studied in scientific works. However, the use of tools that can manage business to customer relationships through CRM software still needs to be developed.

CRM is not a difficult tool to use. To be able to implement operational CRM, business people can provide proof of membership to potential customers. This membership is accompanied by several attractive offers such as special price facilities, special facilities at special events, and so on. They try to carry out proactive interactions with customers by using previous transaction data. In addition, the operational CRM concept that is commonly used is to cooperate with other service providers, such as banking. With CRM implementation like this, business people can achieve optimal results. Barnes (2003) revealed that when technology is widely available and companies have realized the importance of tracking and understanding customer behavior, its existence causes companies to have a close relationship between relationship marketing and database marketing. Thus, the technological capabilities of the customer database enable them to establish relationships with customers. 
The concept of CRM can not be separated from the concept of Relationship marketing. This concept conveys that the main goal targeted by all CRM strategies is economic motive, namely for companies to be able to manage consumer baselines to identify, satisfy and successfully retain the most profitable customers and consumers to become loyal to the product. In addition, CRM is also a marketing process. At the application level, CRM is applied to marketing activities, such as market segmentation, acquiring new customers, maintaining customer loyalty, developing customers, sales campaign management, and opportunity management. But at a strategic level, CRM can be used as a technology that supports the company's mission in an effort to improve customer orientation.

Data about consumers that support a CRM strategy can also be used for various purposes within the company. Operations management can utilize consumer data to design specific products or services for consumers. HR management can use consumer choice data to recruit and train staff who perform tasks directly related to consumers. Research and development management can also use consumer data to assess new products.From the above it can be concluded that the concept of CRM emphasizes the approach to building a company portfolio. Relationships are formed through business relationships between business people and customers through interaction, empowering relationships that are formed, and improving communication with the aim of increasing consumer loyalty. CRM emphasizes collaboration between companies and their customers, this is what distinguishes CRM from marketing concepts in general.

\section{METHODS}

The training is aimed at students majoring in Accounting and Management Muhammadiyah University of Lamongan as beginner entrepreneurs, which is presented in the form of workshops that will be held regularly in an educational format (education and creativity) that involves the five senses, is interactive, interesting and fun. The material is applicable, practical and easily understood by business actors. During the program, the group of participants will be accompanied by a coach, in order to control the progress of their work.

The implementation steps of this training are as follows: 1) Coordinate with the Leaders and Managers of the University of Muhammadiyah Lamongan. Because this training requires approval from the Chancellor of the University of Muhammadiyah Lamongan as the Head of the University; 2) Determine the schedule and place of training; 3) Invite all students of Muhammadiyah University of Lamongan who have a business; 4) Prepare the tools and materials needed for training; 5) Doing direct practice as a form of implementation of the material described; 6) Conduct an evaluation of the results of the training in order to identify the strengths and weaknesses and further develop them; and 6) Making activity reports 


\section{RESULT AND DISCUSSION}

The Customer Relationship Management (CRM) process carried out by accounting and management students begins with collecting data. Accounting and management students collect customer data through the guest book. The guest book contains data on potential customers, suggestions, criticisms, and interests. Every 2 weeks, data on prospective customers and customers are recorded and start sorting out which customers are prospects for the future. Furthermore, the implementation of Customer Relationship Management (CRM) carried out by accounting and management students is to analyze customer databases and convert the data into information that can assist accounting and management students in planning and developing programs for customer loyalty. The next step is the development of a Customer Relationship Management (CRM) program.

Accounting and management students can identify their target customers, as well as decide which customers should receive special offers. Based on this data, accounting and management students prepare programs for their customers every month. The programs that will be made must have definite goals so that in the end they will be evaluated at the end of each month. The program also aims to build relationships with customers. In addition, a program will be made to maintain the existence of accounting and management students in the competition for cafes and food in the city of Lamongan. The stages in implementing the Customer Relationship Management (CRM) program. In implementing the customer program, the goals that have been made must be implemented and need to be focused on the program every month. It takes cooperation from all lines of sections in order to achieve the goals set. In the results of this training, there are three (3) levels of Customer Relationship Management carried out by novice business actors.

First, Strategic CRM aims to build a company that is designed to create and deliver maximum customer value and better than competitors. Strategic CRM includes: organizational structure, cross-departmental collaboration, and organizational culture. 1) organizational structure; This structure section has a special section to handle customer retention and then share information about customers with all parties in the company. Customer service is separate from the marketing and customer service functions or employees in implementing Customer Relationship Management (CRM), 2) Cross-Departmental Cooperation. All work units play a role in the implementation of Customer Relationship Management (CRM) to the fullest. All units play an important role in the successful implementation of Customer Relationship Management (CRM), because if only one unit works, it will not work well. For example, if the Customer service section does not serve and provide information properly, then the customer feels disappointed so that the customer will not make repeat purchases which results in decreased sales and relationships with customers do not go well, and 3) Organizational culture that is built in business people starters are excellent service consisting of smiles, greetings, greetings. This culture is applied to 
novice business people. The purpose of implementing service excellence is to improve service to customers, so that customers feel satisfied and affect the customer's desire to make repeat purchases.

Second, Operational CRM is more focused on developing the automation of the company's ways of dealing with customers. In this case when novice businesses, especially management and accounting students, have to develop marketing automation and service automation, and the three Analytical CRMs are used to exploit customer data to increase their value. This system was developed based on information about customers. The collection, storage, processing and use of customer data information is an important element for a Customer Relationship Management (CRM) strategy. The implementation of this Customer relation Marketing strategy can have a positive influence in improving marketing. This is in accordance with previous research by (Farida, N., Naryoso, A., \& Yuniawan, 2017) that the existence of a Customer Relationship Marketing strategy is able to have a positive and significant impact on increasing marketing. because the better the relationship between consumers and business actors, the higher the level of marketing. Besides entrepreneurs who dare to take risks and have business experience as well as flexible in its business will be able to make consumers believe that consumers will survive existence of training Customer Relationship Management for beginner businessmen conducted by students of Management and Accounting can increase sales future pandemic, given the future The pandemic has drastically decreased in the service, culinary, and other convection sectors. So, in other words, with this training, business actors can increase sales. Management and Accounting students can classify and analyze customer profiles and can provide and improve customer service so as to create customer loyalty. These results are in accordance with the research of Rosanti, et al (2020) explaining that by improving customer service or customers, it is necessary to carry out a relationship marketing program to increase customer loyalty to visit and gain trust in the companies they manage.

Besides, it is also hoped that with the Customer Relationship Management training, Management and Accounting students can manage and implement identification programs, understanding programs, relationship programs and sales programs, and can manage Customer Relationship Management programs effectively and efficiently so as to increase sales. In the last stage of training, Customer Relationship Management will evaluate the implementation of customer programs as the implementation of Customer Relationship Management (CRM) must be improved to measure the risk of miscommunication in delivering and understanding the program that is held every month. Alfin (2021) with research results stated that the relationship strategy can establish relationships between customers and foster consumer confidence so that consumers survive with our products. The results of the study are in line with (Hardilawati, 2019) giving different results where Customer Relationship Marketing is able to provide a positive but not significant influence on the marketing of business 
actors. This is because business actors are not always able to carry out customer relationship marketing well.

\section{CONCLUSION}

It can be concluded that with the existence of Customer Relationship Management (CRM) training is needed in a company, not only applies to large-scale companies, small-scale companies (MSMEs) also need to pay attention to this problem. Given the current competitive era, the role of the brand in a product is very important as the identity of the product in order to differentiate it from competing products. Besides that, during the pandemic, of course, it is necessary to improve good service so that customers don't move to other hearts. From the results of the training conducted, it can be concluded that Management and Accounting students have not developed Customer Relationship Management (CRM) to maintain customer loyalty.

\section{REFERENCES}

[1] Alfin, A. (2021). Analisis Strategi UMKM dalam Menghadapi Krisis di Era Pandemi Covid-19. Jurnal Inovasi Pendidikan, 1(8), 1543-1552.

[2] Barnes, J. G. (2003). Secret of Customer Relationship Management (Rahasia Manajemen Hubungan Pelanggan). Yogyakarta: Andi.

[3] Farida, N., Naryoso, A., \& Yuniawan, A. (2017). Model of Relationship Marketing and E-Commerce in Improving Marketing Performance of Batik SMEs. Jurnal Dinamika Manajemen, 8(1), 20-29.

[4] Hardilawati, W. L. (2019). Model Pemasaran Hubungan Pelanggan, Inovasi Dan ECommerce Dalam Meningkatkan Kinerja Pemasaran Ukm Di Pekanbaru. Jurnal Akuntansi Dan Ekonomika, 9(2), 213-222.

[5] Laucereno, S. F. (2020). Sederet Dampak Corona Terhadap Bisnis di Indonesia. Retrieved May 20, 2021, from 12/03/2020 website: https://finance.detik.com/beritaekonomi-bisnis/d-4935727/sederet-dampak-corona-terhadap-bisnis-di-indonesia

[6] Perkasa, G. (2020). Berubahnya Bisnis Kuliner di Masa Pandemi Covid-1. Retrieved March 2021, from 20/04/2020 website: https://ifestyle.kompas.com/read/2020/04/20/132308820/berubahnya-bisnis-kuliner-dimasa-pandemi-covid-19?page=all

[7] Rosanti, Y., Irawan, M \& Putra, D. T. (2020). Tantangan dan Strategi Customer Relationship Marketing dengan Prinsip Cleanliness, Health, and Safety (CHS) dalam Upaya Pemulihan Ekonomi di Kawasan Wisata Samosir. Konferensi Nasional Ekonomi Manajemen Dan Akuntansi, 1-13. Jakarta: Universitas Muhammadiyah Jakarta.

[8] Singh, R \& Khan, I. (2012). An Approach to Increase Customer Retention and Loyality in B2C World. International Journal of Scientific and Research Publications, 2(6). 